Research Article

\title{
Induction of SCEs and DNA fragmentation in bovine peripheral lymphocytes by in vitro exposure to tolylfluanid-based fungicide
}

\author{
Katarína Siviková, Ján Dianovsky and Beáta Holecková \\ Institute of Genetics, University of Veterinary Medicine and Pharmacy, Kosice, Slovak Republic.
}

\begin{abstract}
The potential for genotoxic and cytotoxic effects of tolylfluanid-based fungicide ( $50 \%$ active agent) was evaluated using sister chromatid exchange (SCE) and proliferation indices (PI) in cultured bovine peripheral lymphocytes. For the detection of possible genetic damage, DNA fragmentation assay was also applied. Bovine lymphocytes cultured for $72 \mathrm{~h}$ were treated with the fungicide at the final concentrations of $1.75,3.5,8.75$, and $17.5 \mu \mathrm{g} / \mathrm{mL}$ for the last 24 and $48 \mathrm{~h}$ of culture without S9 metabolic activation, and during the last $2 \mathrm{~h}$ of culture with S9 metabolic activation. In the SCE assays no evidence for genotoxic activity of the fungicide was found in treatments of $24 \mathrm{~h}$ without and $2 \mathrm{~h}$ with S9. After the $24 \mathrm{~h}$ exposure to tolylfluanid, a weak decrease in the PI was observed. With the prolonged exposure time (48 h), dose dependence in the increase of SCE frequencies was observed. Moreover, after $48 \mathrm{~h}$ exposure slight fragmentation of DNA at the concentrations of 3.5 and $8.75 \mu \mathrm{g} / \mathrm{mL}$ was demonstrated. SCE quantification is the most widely used approach for the assessment of genotoxic/cytogenetic effects of chemical compounds. Positive results in the assay at $48 \mathrm{~h}$ exposure indicated a potential of the fungicide to increase frequency of chromosomal damage (replication injuries) that is the confirmation of early effect of exposure.
\end{abstract}

Key words: tolylfluanid-based fungicide, sister chromatid exchanges, DNA fragmentation.

Received: March 12, 2010; Accepted: July 8, 2010.

\section{Introduction}

Tolylfluanid is a member of the phenylsulfamide group of fungicides and it has been applied in agriculture for control of fungal diseases during thinning, pruning, and harvesting fruits and vegetables (Tielemans et al., 1999, Stajnbaher and Zupancic-Kralj, 2008). Fungicides such as tolylfluanid, captan, cyprodinil, tebuconazole, etc., tend to be more often detected in vegetables and fruits than are insecticides or herbicides (Looser et al., 2006, Basa Cesnik et al., 2006, Tichá et al., 2008, Knezevi et. al., 2009). Tolylfluanid has also been used as an alternative antifouling compound (Bellas, 2006, Links et al., 2007, Takahashi 2009).

The acute toxicity of the fungicide was assessed to be low for mammalian cells and it was established as a readily absorbed and rapidly hydrolysed agent within $48 \mathrm{~h}$ (Pesticide Residues in Food - Joint FAO/WHO Meeting on Pesticide Residues, 2002). As regards genotoxic activity, tolylfluanid was reported as weakly clastogenic in Chinese hamster V79 cells in the presence of S9 metabolic activation. In mammalian chromosome aberration assay in vitro with and without S9 the cytotoxic effect of the fungicide was confirmed at concentrations of 1 to $10 \mu \mathrm{g} / \mathrm{mL}(-\mathrm{S} 9)$ and

Send correspondence to Katarína Siviková. Institute of Genetics, University of Veterinary Medicine and Pharmacy, Komenského 73, 04181 Kosice, Slovak Republic. E-mail: sivikova@uvm.sk.
5 to $10 \mu \mathrm{g} / \mathrm{mL}(+\mathrm{S} 9)$. On the basis of these findings, tolylfluanid was recognized by the United States Environmental Protection Agency (EPA, 2002) as a non-genotoxic agent both to bacteria and mammal cells. In further studies using Crg96 mutants of Pseudomonas corrugate (defective in the $\operatorname{Rec} G$ gene encoding a RecG helicase); Decorosi et al. (2009) described an increased sensitivity of this mutant strain to the fungicides captan and tolylfluanid. Crg96 mutant was sensitive to numerous genotoxic compounds that are known to induce inhibition of DNA replication.

Several recent studies demonstrated the adverse effects of persistent exposure to pesticides including tolylfluanid and the related dichlofluanid on the integrity of immune (Pistl et al., 2003), nervous, endocrine (Rhind, 2002, Odermatt et al., 2006), and reproductive systems (Costa et al., 2006).

The results on possible cytogenetic and genotoxic effects of tolylfluanid in animal or human cells are insufficient or incomplete. Genotoxic potential of chemical agents represents a primary risk factor for long-term effects such as carcinogenic or reproductive disorders (Bolognesi, 2003). Pauluhn (2004) investigated acute lung edema induction in rats after exposure to naphthylene diisocyanate aerosols and tolylfluanid. They could show that protein concentration in bronchoalveolar lavage fluid, a sensitive 
early marker of lung edema was increased in rats exposed to tolylfluanid solid aerosol in size less than $3 \mu \mathrm{m}$.

The aim of our research was to investigate early effects of exposure to tolylfluanid-based fungicide in cultured bovine peripheral lymphocytes using sister chromatid exchanges (SCE) and proliferation indices (PI) to assess the cell cycle delay/cytotoxicity. Besides the cytogenetic markers, fragmentation of DNA as a prominent feature of apoptosis was investigated to evaluate the possible effect of tolylfluanid-based fungicide in the induction of apoptosis in peripheral lymphocytes of cattle. These parameters were analyzed because an indirect genotoxic mechanism (e.g., oxidative stress), or a mechanism involving significant cytotoxicity leading to compensatory increase in cell proliferation are considered to be a limiting step in tumorigenesis (Benford et al. 2010). Furthermore, apoptotic cell death is reflected by the degradation of genomic DNA by an endogenous endonuclease. (López Nigro and Carballo, 2008).

\section{Material and Methods}

The tolylfluanid formulation fungicide (1,1-dichloro-N-[(dimethylamino) sulfonyl]-1-fluoro-N-(4-methylphenyl) methanesulfonamide (Bayer AG, Germany), containing $50 \%$ active agent, was dissolved in dimethyl sulfoxide (DMSO, Sigma, St. Louis, MO, USA) and added to culture media at the final concentrations of $1.75,3.5$, 8.75 , and $17.5 \mu \mathrm{g} / \mathrm{mL}$. The fungicide dose levels were chosen beforehand, taking into account the highest concentration for testing $(17.5 \mu \mathrm{g} / \mathrm{mL})$ causing a reduction in the mitotic index $(\mathrm{MI}>50 \%)$.

Mitomycin C (MMC, Sigma, St. Louis, MO, USA, $0.4 \mu \mathrm{M})$ and cyclophosphamide (CPA, Jenapharm, Ankerwerk, Rudolstadt, Germany, $4 \mu \mathrm{g} / \mathrm{mL}$ ) were used as positive control agents in the assays with absence and presence of the metabolic activation ( $\mathrm{S} 9 \mathrm{mix}$ ), respectively.

Blood was obtained from two healthy young bulls (Slovak spotted cattle, 6 months old). For the SCE assays, experiments were made both in the presence and in the absence of the S9 mix. A freshly prepared S9 fraction ( $10 \%$ of the culture volume) from Aroclor 1254 (Supelco, Bellefonte, PA, USA) induced mice was prepared according to the method of Maron and Ames (1983) and applied to the control and experimental cultures. Glucoso-6-phosphate (Aldrich, Milwaukee, WI, USA) and NADP (Sigma, St. Louis, MO, USA) were used as cofactors.

\section{Cell cultivation}

Whole blood cultures $(0.5 \mathrm{~mL})$ were cultivated for $72 \mathrm{~h}$ at $38^{\circ} \mathrm{C}$ in $5 \mathrm{~mL}$ of RPMI 1640 medium supplemented with L-glutamine, $15 \mu \mathrm{M}$ HEPES (Sigma, St. Louis, MO, USA), $15 \%$ foetal calf serum, antibiotics (penicillin $250 \mathrm{U} / \mathrm{mL}$ and streptomycin $250 \mu \mathrm{g} / \mathrm{mL}$ ), and phytohae- magglutinin (PHA, $180 \mu \mathrm{g} / \mathrm{mL}$, Welcome, Dartford, England).

Chromosome preparations were obtained by the standard cytogenetic method; $2 \mathrm{~h}$ before harvest, colchicine (Merck, Darmstadt, Germany) was added at the $5 \mu \mathrm{g} / \mathrm{mL}$ concentration. Lymphocyte cultures without the S9 fraction were exposed to the fungicide for the last $24 \mathrm{~h}$ (the basic exposure to the agent, Tucker and Preston, 1996) or $48 \mathrm{~h}$ of cultivation. Long-term exposure to the agent (for $48 \mathrm{~h}$ ) provides additional information about the cytotoxic as well as cytostatic effects. Cultures with the S9 (modification of metabolic activation of substance) were treated with the fungicide during the final $2 \mathrm{~h}$ according to Johnson et al. (1996). Then the cells were washed two times with medium and placed in complete fresh culture medium.

For the SCE assay and the cell cycle kinetics, bromodeoxyuridine ( $8 \mu \mathrm{g} / \mathrm{mL}$, BrdUrd, Sigma, St. Louis, MO, USA) was added to all the cultures $24 \mathrm{~h}$ after initiation. Slides were stained with Giemsa for CAs or with FPG technique to differentiate sister chromatids and cell cycles as previously described elsewhere (Siviková and Dianovsky, 1999, 2006). Fifty differentially stained metaphases and one hundred metaphases for determination of $\mathrm{M}_{1}, \mathrm{M}_{2}$, and $\mathrm{M}_{3+}$ mitotic divisions were examined. The proliferation indices (PI) were calculated according to Lamberti et al. (1983).

\section{DNA ladder assay}

DNA fragmentation was analyzed after the $24 \mathrm{~h}$ and $48 \mathrm{~h}$ exposure to tolylfluanid in bovine peripheral lymphocytes using the same concentrations as for the cytogenetic assays. DNA ladder fragment analysis was performed according to Cotter and Martin (1996) by means of the Apoptotic DNA Ladder Kit (Roche Diagnostics GmbH, Mannheim, Germany). Lymphocyte cultures without and with DMSO $(0.1 \%)$ were used as negative controls. Apoptotic U937 cells of the kit (cell cultures treated with $4 \mu \mathrm{g} / \mathrm{mL}$ camptothecin for $3 \mathrm{~h}$ ) served as a positive control. After incubation, the cells were collected by centrifugation at $500 \mathrm{~g}$ for $10 \mathrm{~min}$. The supernatant was removed and the cell pellets were washed twice with PBS buffer ( $\mathrm{pH}$ 7.2). DNA was isolated from a $200-300 \mu \mathrm{L}$ sample as specified according to the manufacturer's protocol. Briefly, after lysis of cultured cells in binding/lysis buffer $(6 \mathrm{mM}$ guanidine-HCL, $10 \mathrm{mM}$ urea, $10 \mathrm{mM}$ TRIS-HCl, $20 \%$ TritonX-100, $\mathrm{pH} 4.4$ ), the lysate was applied to a filter tube and passaged by centrifugation through the glass fiber fleece of this tube. Nucleic acid specifically binding to the surface of the glass fibres, was washed with $20 \mathrm{mM} \mathrm{NaCl}$ and $2 \mathrm{mM}$ TRIS- $\mathrm{HCl}(\mathrm{pH} \mathrm{7.5)}$ to clean the cellular impurities off the fleece and eluted using $10 \mathrm{mM}$ TRIS elution buffer ( $\mathrm{pH} \mathrm{8.5)}$ at $70^{\circ} \mathrm{C}$. The extracted DNA was analysed by electrophoresis in a $1.5 \%$ agarose gel, stained with ethidium bromide (Merck, Darmstadt, Germany), examined under ultraviolet (UV) light, and photographed. 


\section{Statistical analysis}

Analysis of variance (ANOVA) was used for statistical analysis followed by the Student's t-test for the comparison of SCE occurrence between treated and untreated groups. A $\chi^{2}$ test was applied to evaluate cell cycle delay.

\section{Results}

\section{Cytogenetic studies}

Tables 1 to 3 show the data obtained from the cytogenetic experimental conditions: $24 \mathrm{~h}, 48 \mathrm{~h}$, and $2 \mathrm{~h}$ of exposure to tolylfluanid-based fungicide in cultured bovine lymphocytes without and with metabolic activation.

In the SCE study for $24 \mathrm{~h}$, no dose dependence in the increases of sister chromatid exchanges was observed. A statistically significant elevation in chromosomal damage was seen after the fungicide exposure at the highest concentration $(17.5 \mu \mathrm{g} / \mathrm{mL}, \mathrm{p}<0.01$, Student's t- test) in both of the donors, however only an insufficient number of cells could be analyzed in the donor 1. A weak decrease $(p<0.05)$ in proliferation indices (PI) was observed at the fungicide concentration range

Table 1 - Frequency of SCEs and proliferation indices in cultured bovine peripheral lymphocytes exposed to the tolylfluanid-based fungicide for $24 \mathrm{~h}$.

\begin{tabular}{|c|c|c|}
\hline Dose & $\mathrm{SCE} /$ cell & PI \\
\hline & \multicolumn{2}{|c|}{ Donor 1} \\
\hline Control (DMSO) & $6.98 \pm 2.92$ & 1.76 \\
\hline \multicolumn{3}{|l|}{$\begin{array}{l}\text { Tolylfluanid-based fungicide } \\
(\mu \mathrm{g} / \mathrm{mL}) 24 \mathrm{~h}\end{array}$} \\
\hline 1.7 & $7.50 \pm 3.45^{\mathrm{a}}$ & $1.66^{\mathrm{a}}$ \\
\hline 3.5 & $7.64 \pm 3.21^{\mathrm{a}}$ & $1.61^{*}$ \\
\hline 8.75 & $8.00 \pm 2.28^{\mathrm{a}}$ & $1.59 *$ \\
\hline 17.5 & $8.85 \pm 2.22^{* *, b}$ & $1.53 * *$ \\
\hline \multirow[t]{2}{*}{ Positive control, $0.4 \mu \mathrm{M}$ MMC } & $9.74 \pm 2.76^{* * *}$ & $1.65^{\mathrm{a}}$ \\
\hline & \multicolumn{2}{|c|}{ Donor 2} \\
\hline Control (DMSO) & $7.18 \pm 2.43$ & 1.62 \\
\hline \multicolumn{3}{|l|}{$\begin{array}{l}\text { Tolylfluanid-based fungicide } \\
(\mu \mathrm{g} / \mathrm{mL}) 24 \mathrm{~h}\end{array}$} \\
\hline 1.7 & $7.56 \pm 2.77^{\mathrm{a}}$ & $1.63^{\mathrm{a}}$ \\
\hline 3.5 & $7.71 \pm 3.06^{\mathrm{a}}$ & $1.52^{\mathrm{a}}$ \\
\hline 8.75 & $8.12 \pm 2.82^{\mathrm{a}}$ & $1.47 *$ \\
\hline 17.5 & $9.25 \pm 3.37 * *, \mathrm{c}$ & $1.45^{*}$ \\
\hline Positive control $0.4 \mu \mathrm{M}, \mathrm{MMC}$ & $9.86 \pm 2.30^{* * *}$ & $1.54^{\mathrm{a}}$ \\
\hline
\end{tabular}

A total of 50 second-division metaphases of each group were analyzed for SCE, where possible. ${ }^{*}(\mathrm{p}<0.05),{ }^{* *}(\mathrm{p}<0.01),{ }^{* * *}(\mathrm{p}<0.001)$, ANOVA followed by Student's $t$ test was used for SCE and $\chi^{2}$ test for PI evaluation a - no statistical significance, b, c - insufficient number of cells: ${ }^{2} 27,{ }^{c} 28$ analyzed second metaphases.
3.5-17.5 $\mu \mathrm{g} / \mathrm{mL}$. More expressive inhibition in the proliferation activity of tolylfluanid-based fungicide was seen in the donor 1 after the exposure to the highest concentration $(\mathrm{p}<0.01$, Table 1$)$.

The prolonged time of exposure caused significant elevations in SCE frequencies with a dose dependence. However, a decrease in proliferation indices and the induction of cell cycle delays was not denoted ( $48 \mathrm{~h}$, Table 2 ).

Similarly, in the SCE assay with $2 \mathrm{~h}$ exposure for metabolic activation no statistically significant increase in the SCE frequency was found. A weak decrease in proliferation indices was observed at the highest concentration of the fungicide (Table 3).

\section{DNA fragmentation and cell death evaluation}

At a $24 \mathrm{~h}$ exposure to tolylfluanid-based fungicide, no DNA fragments were recorded in bovine lymphocyte cultures at any concentration tested. On the contrary, a slight fragmentation of DNA was visible after the prolonged time of exposure to the fungicide. Nucleosomal laddering of cultivated lymphocyte was demonstrated at the concentrations of 3.5 and $8.75 \mu \mathrm{g} / \mathrm{mL}$ (Figure 1).

Table 2 - Frequency of SCEs and proliferation indices in cultured bovine peripheral lymphocytes exposed to the tolylfluanid-based fungicide for $48 \mathrm{~h}$.

\begin{tabular}{|c|c|c|}
\hline Dose & $\mathrm{SCE} /$ cell & PI \\
\hline & \multicolumn{2}{|c|}{ Donor 1} \\
\hline Control (DMSO) & $6.40 \pm 2.41$ & 1.76 \\
\hline \multicolumn{3}{|l|}{$\begin{array}{l}\text { Tolylfluanid-based fungicide } \\
(\mu \mathrm{g} / \mathrm{mL}) 48 \mathrm{~h}\end{array}$} \\
\hline 1.7 & $7.05 \pm 2.64^{\mathrm{a}}$ & $1.76^{\mathrm{a}}$ \\
\hline 3.5 & $7.94 \pm 3.41 * *$ & $1.73^{\mathrm{a}}$ \\
\hline 8.75 & $8.46 \pm 2.76^{* * *}$ & $1.73^{\mathrm{a}}$ \\
\hline 17.5 & $9.25 \pm 3.29 * * *$ & $1.68^{\mathrm{a}}$ \\
\hline \multirow[t]{2}{*}{ Positive control, $0.4 \mu \mathrm{M}$ MMC } & $23.2 \pm 3.9 * * *$ & $1.54 * *$ \\
\hline & \multicolumn{2}{|c|}{ Donor 2} \\
\hline Control (DMSO) & $6.82 \pm 3.02$ & 1.62 \\
\hline \multicolumn{3}{|l|}{$\begin{array}{l}\text { Tolylfluanid-based fungicide } \\
(\mu \mathrm{g} / \mathrm{mL}) 48 \mathrm{~h}\end{array}$} \\
\hline 1.7 & $7.72 \pm 2.84^{\mathrm{a}}$ & $1.62^{\mathrm{a}}$ \\
\hline 3.5 & $8.32 \pm 3.04^{*}$ & $1.54^{\mathrm{a}}$ \\
\hline 8.75 & $8.88 \pm 3.43 * *$ & $1.53^{\mathrm{a}}$ \\
\hline 17.5 & $9.49 \pm 3.48^{* * *}$ & $1.58^{\mathrm{a}}$ \\
\hline Positive control $0.4 \mu \mathrm{M}, \mathrm{MMC}$ & $24.5 \pm 4.8^{* * *}$ & $1.47^{* *}$ \\
\hline
\end{tabular}

A total of 50 second-division metaphases of each group were analysed for SCE.

$*(\mathrm{p}<0.05), * *(\mathrm{p}<0.01), * * *(\mathrm{p}<0.001)$, ANOVA followed by Student's $\mathrm{t}$ test was used for SCE and $\chi^{2}$ test for PI evaluation a - no statistical significance. 
Table 3 - Frequency of SCEs and proliferation indices in cultured peripheral lymphocytes exposed to the tolylfluanid-based fungicide for $2 \mathrm{~h}$ with S9.

\begin{tabular}{lcc}
\hline Dose & SCE / cell & PI \\
\hline \multicolumn{2}{c}{ Donor 1} \\
Control (DMSO) & \multicolumn{2}{c}{1.75} \\
Tolylfluanid-based fungicide & & \\
$(\mu \mathrm{g} / \mathrm{mL}) 2 \mathrm{~h}+\mathrm{S} 9$ & & \\
1.7 & $7.15 \pm 2.94^{\mathrm{a}}$ & $1.80^{\mathrm{a}}$ \\
3.5 & $7.26 \pm 3.12^{\mathrm{a}}$ & $1.80^{\mathrm{a}}$ \\
8.75 & $7.44 \pm 3.54^{\mathrm{a}}$ & $1.76^{\mathrm{a}}$ \\
17.5 & $7.73 \pm 2.99^{\mathrm{a}, \mathrm{b}}$ & $1.64^{*}$ \\
$4 \mu \mathrm{g} / \mathrm{mL}$, cyclophosphamid & $11.96 \pm 4.46^{* * *}$ & $1.57^{* *}$
\end{tabular}

Donor 2

Control (DMSO)

$7.07 \pm 2.86$

Tolylfluanid-based fungicide $(\mu \mathrm{g} / \mathrm{mL}) 2 \mathrm{~h}+\mathrm{S} 9$

\begin{tabular}{lcc}
1.7 & $7.13 \pm 2.90^{\mathrm{a}}$ & $1.73^{\mathrm{a}}$ \\
3.5 & $7.22 \pm 2.86^{\mathrm{a}}$ & $1.75^{\mathrm{a}}$ \\
8.75 & $7.34 \pm 2.67^{\mathrm{a}}$ & $1.73^{\mathrm{a}}$ \\
17.5 & $7.63 \pm 3.64^{\mathrm{a}, \mathrm{c}}$ & $1.56^{*}$ \\
$4 \mu \mathrm{g} / \mathrm{mL}$, cyclophosphamid & $10.19 \pm 5.24^{* * *}$ & $1.47^{* * *}$ \\
\hline
\end{tabular}

A total of 50 second-division metaphases of each group were analyzed for SCE, where possible. $*(\mathrm{p}<0.05), * *(\mathrm{p}<0.01), * * *(\mathrm{p}<0.001)$, ANOVA followed by Student's t test was used for SCE and $\chi^{2}$ test for PI evaluation a - no statistical significance, b, c-insufficient number of cells: ${ }^{b} 27,{ }^{c} 28$ analyzed second metaphases.

\section{Discussion}

We present herein the results of cytogenetic studies using SCE and PI as biomarkers, as well those on DNA fragmentation as a biochemical distinctive feature of apoptotic cell death.

The results of the SCE studies were dependent on the time of exposure to the fungicide. No increase in SCE induction was observed after a $24 \mathrm{~h}$ incubation. The treatment with the highest dose of the tested fungicide was demonstrated to cause an increase in SCE frequency in both donors, yet only incomplete second metaphases could be analysed in donor 1 . Reduction in the PI percentage reflected a weak delay in cell proliferation.

A dose-related response in the induction of SCE was observed in cultures exposed to tolylfluanid-based fungicide for $48 \mathrm{~h}$. Influence on proliferation kinetics of bovine lymphocytes was not found. In contrast, the SCE results for the $2 \mathrm{~h}$ exposure with metabolic activation (S9) were inadequate to confirm any genotoxic activity of the fungicide tested.

SCE quantification is the most widely used approach for the assessment of the genotoxic/cytogenetic effects of various chemical compounds, and is considered to be a

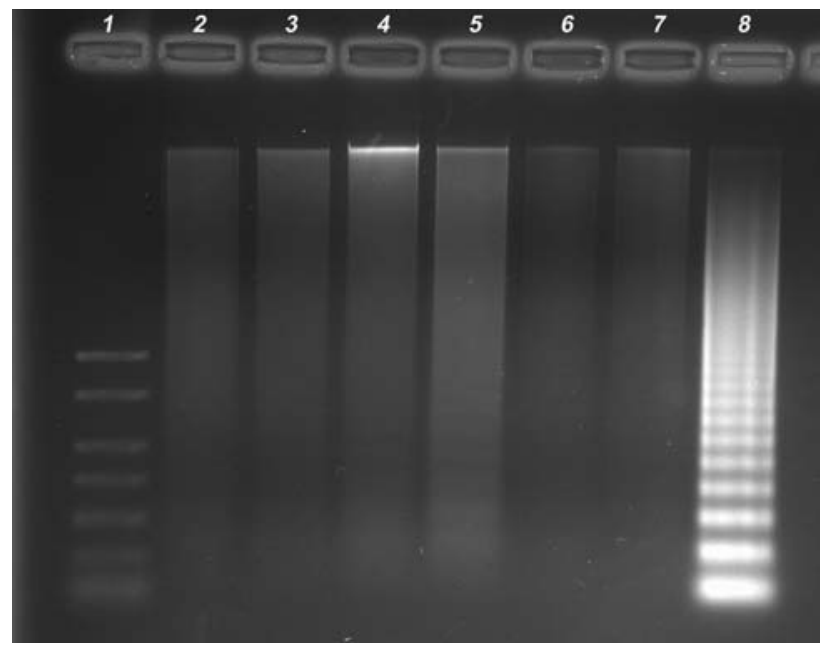

Figure 1 - DNA gel electrophoresis of internucleosomal DNA fragmentation in $1.5 \%$ agarose gel after the exposure to tolylfluanid-based fungicide for $48 \mathrm{~h}$. A slight fragmentation of DNA was demonstrated at the concentrations of 3.5 and $8.75 \mu \mathrm{g} / \mathrm{mL}$. (1) Marker MW (2) DMSO (3) $1.75 \mu \mathrm{g} / \mathrm{mL}$ (4) $3.50 \mu \mathrm{g} / \mathrm{mL}$ (5) $8.75 \mu \mathrm{g} / \mathrm{mL}$ (6) $17.5 \mu \mathrm{g} / \mathrm{mL}$ (7) Negative control without treatment (8) Positive control (U937 cells).

measure of the dose as they also detect early effects of exposure (Albertini, 1998). Analysis of the SCE was adopted as an indicator of genotoxicity, although the mechanism of SCE induction is still unknown. Recent studies revealed that imbalance of the nucleotide pool can have severe consequences on DNA metabolism which is a critical point in SCE formation (Bolognesi, 2003).

Studies regarding the clastogenic/cytogenetic effects of tolylfluanid in farm animals are scant. Previously we performed experiments with bovine peripheral lymphocytes to detect the in vitro clastogenic effect of tolylfluanid formulation fungicide incubated for $24 \mathrm{~h}$ and $48 \mathrm{~h}$. No clastogenic effect of the fungicide was observed using conventional chromosome aberration analysis (with Giemsa staining) or fluorescence in situ hybridisation (FISH) (Orosová et al., 2010).

Few authors have documented toxicity of tolylfluanid. Bellas (2006) compared the toxicity of four biocides (chlorothalonil, dichlofluanid, tolylfluanid, and Irgarol) on early developmental stages of marine invertebrates. The highest toxicity to embryos and larvae of Mytilus edulis and sea-urchins was seen after the application of chlorothalonil and dichlofluanid. Pistl et al. (2003) demonstrated a significant cytotoxic effect of dichlofluanid at a concentration of $10^{-1} \mathrm{M}$ in ovine peripheral leucocytes. The authors denoted a more expressive immunotoxic effect when cultures of ovine lymphocytes were treated with the fungicide after PHA proliferation stimulation. Similarly Holovská et al. (2007) described a significant suppression of the proliferative activity in RK13 cells after exposure to tolylfluanid at a concentration of $10^{-4} \mathrm{M}$.

Apoptosis (or programmed cell death) has been shown to be initiated by several factors, including exposure 
to the pesticides (Kannan et al., 2000, Li et al., 2009). The effect of different groups of pesticides in apoptosis induced DNA fragmentation, has been investigated. Kaur et al. (2007) reported that low-level long-term organophosphate exposure resulted in oligonucleosomal DNA fragmentation as a hallmark of apoptosis. A derivative of the carbamate pesticide carbofuran, N-nitrosocarbofuran, induced apoptosis of Chinese hamster lung fibroblast cells (Yoon et al., 2001). Multiple in vitro exposures of mouse thymocytes to pesticide were examined by Olgun $e t$ al. (2004). As regards tolylfluanid formulation (with 50\% active agent), Domaracky et al. (2007) reported cell death in mouse preimplantation embryos at relatively low doses. Nevertheless, the incidence of cell death has been mostly reported as necrosis.

No differences in DNA fragmentation among bovine culture samples on the agarose gel were observed after $24 \mathrm{~h}$ exposure. Nevertheless, a prolonged time of treatment with tolylfluanid-based fungicide at concentrations of 3.50 and $8.75 \mu \mathrm{g} / \mathrm{mL}$ resulted in a weak nucleosomal DNA ladder pattern. Apoptosis is thought to contribute to the elimination of the cells which might undergo irreversible transformation (Elhajouji et al., 1997). At the highest concentration of the fungicide, the cells are probably adapted to the changes and thus no DNA ladder formation occurs (Decordier et al., 2008). DNA fragmentation appears to be time-dependent and corresponds with the cell kinetics of our cytogenetic studies, where a delay of cell proliferation and cytotoxic/cytostatic effects of the fungicide could be denoted.

Positive results in the SCE assay for the $48 \mathrm{~h}$ treatment indicated that the fungicide has the potential to induce chromosomal damage (replication injuries). Based on our results in all of the experimental conditions, we suggest that tolylfluanid-based fungicide acts as a multi-site inhibitor (microtubule and proliferation inhibitors) and that in high concentrations could block cell division. There is evidence for an association of environmental chemical agents (including pesticides) with disturbing of glucocorticoidregulated physiological processes. Xenobiotics that interfere with glucocorticoid-mediated functions are expected to disturb the cellular energy status by altering the expression of genes involved in carbohydrate, lipid, or protein metabolism. Glucocorticoid activation was also observed for tolylfluanid, hexachlorobenzene, and others, with $\mathrm{IC}_{50}$ values of about $1 \mathrm{mM}$ promoting cell cycle arrest in the $\mathrm{G}_{1}$-phase (Johansson et al., 2005, Odermatt and Gumy, 2008). Taken together we infer that, environmental contamination with the fungicide can contribute to increase genetic risk for humans.

\section{Acknowledgments}

This work was supported by the Slovak Research and Development Agency under contract No. APVV-0010-07,
VEGA 1/0334/10, and by the National Reference Laboratory for Pesticides at UVM.

\section{References}

Albertini RJ (1998) The use and interpretation of biomarkers of environmental genotoxicity in humans. Biotherapy 11:155167.

Basa Cesnik H, Gregorcic A, Velikonja Bolta S and Kmecl V (2006) Monitoring of pesticide residues in apples, lettuce and potato of the Slovene origin, 2001-04. Food Addit Contam 23:164-173.

Bellas J (2006) Comparative toxicity of alternative antifouling biocides on embryos and larvae of marine invertebrates. Sci Total Environ 367:573-585.

Benford D, Bolger PM, Carthew P, Coulet M, DiNovi M, Leblanc JC, Renwick AG, Setzer W, Schlatter J, Smith B et al. (2010) Application of the margin of exposure (MOE) approach to substances in food that are genotoxic and carcinogenic. Food Chem Toxicol 48:S2-S24.

Bolognesi C (2003) Genotoxicity of pesticides: A review of human biomonitoring studies. Mutat Res 543:251-272.

Costa C, Teixeira JP, Silva S, Roma-Torres J, Coelho P, Gaspar J, Alves M, Laffon B, Rueff J and Mayan O (2006) Cytogenetic and molecular biomonitoring of a Portugese population exposed to pesticides. Mutagenesis 21:343-350.

Cotter TG and Martin SJ (1996) Techniques in Apoptosis: A User's Guide. Portland Press, London, 344 pp.

Decordier I, Cundari E and Kirsh-Volders M (2008) Mitotic checkpoints and the maintenance of the chromosome karyotype. Mutat Res 651:3-13.

Decorosi F, Tatti E, Mini A, Giovannetti L and Viti C (2009) Characterization of two genes involved in chromate resistance in a $\mathrm{Cr}(\mathrm{VI})$-hyper-resistant bacterium. Extremophiles 13:217-223.

Domaracky M, Rehák J, Legáth J and Koppel J (2007) Effects of fungicide Euparen Multi (tolylfluanid) on development of preimplantation embryos in mouse. Acta Vet Brno 76:209214.

Elhajouji A, Geleyns K, Cunha M, Fulton WB, Tuynder M, Cundari E and Kirsch-Volders M (1997) Mitotic-spindle poisons (nocodazole and taxol) induce apoptosis by p53-dependent and -independent pathways. Mutat Res 379(Suppl 1):50.

Holovská V, Pistl J and Kovalkovicová N (2007) In vitro effect of pesticides (dichlofluanid, endosulfan, simazine, tolylfluanid and triallate) on proliferative activity of animal derived cell cultures. Acta Biol Hung 58:61-74.

Johansson M, Johansson N and Bert-Ove Lund (2005) Xenobiotics and glucocorticoid receptor: Additive antagonistic effects on tyrosine aminotransferase activity in rat hepatoma cells. Basic Clin Pharmacol Toxicol 96:309-315.

Johnson TE, Umbenhauer DR and Galloway SM (1996) Human liver S-9 metabolic activation. Environ Mol Mut 28:51-59.

Kannan K, Holcombe RF, Jain SK, Alvarez-Hernandez X, Chervenak R, Wolf RE and Glass J (2000) Evidence for the induction of apoptosis by endosulfan in a human T-cell leukemic line. Mol Cell Biochem 205:53-66.

Kaur P, Radotr B, Ranjana W, Minz RW and Gill KD (2007) Impaired mitochondrial energy metabolism and neuronal apop- 
totic cell death after chronic dichlorvos (OP) exposure in rat brain. Neurotoxicology 28:1208-1219.

Knezevi Z and Serdar M (2009) Screening of fresh fruit and vegetables for pesticide residues on Croatian market. Food Control 20:419-422.

Lamberti L, Ponzetto BP and Ardito G (1983) Cell kinetics and sister chromatid exchange frequency in human lymphocytes. Mutat Res 120:193-199.

Li Q, Kobayashi M and Kawada T (2009) Chlorpyrifos induces apoptosis in human T cells. Toxicology 255:53-57.

Links I, Van Der Jagt KE, Christopher Y, Lurvink M, Schinkel J, Tielemans E and Van Hemmen JJ (2007) Occupational exposure during application and removal of antifouling Paints. Ann Occup Hyg 51:207-218.

Looser N, Kostelac D, Schebaum E, Anastassiades M and Zipper $H$ (2006) Pesticides residues in strawberries sampled from the market of the Federal State of Baden-Württemberg in the period between 2002 and 2005. J Verbr Lebensm 1:135-141.

López Nigro MM and Carballo MA (2008) Genotoxicity and cell death induced by tinidazole (TNZ). Toxicol Lett 180:46-52 .

Maron DM and Ames BN (1983) Revised methods for the Salmonella mutagenicity test. Mutat Res 113:173-215.

Odermatt A and Gumy C (2008) Glucocorticoid and mineralocorticoid action: Why should we consider influences by environmental chemicals? Biochem Pharmacol 76:1184-1193.

Odermatt A, Gumy C, Atanasov AG and Dzyakanchuk AA (2006) Disruption of glucocorticoid action by environmental chemicals: Potential mechanisms and relevance. J Steroid Biochem 102:222-231.

Olgun S, Gogal RM Jr, Adeshina F, Choudhury H and Misra HP (2004) Pesticide mixtures potentiate the toxicity in murine lymphocytes. Toxicology 196:181-195.

Orosová M, Holecková B, Siviková K and Dianovsky J (2010) Effect of fungicide EUPAREN MULTI (tolylfluanid) on the induction of chromosomal aberrations in cultivated bovine lymphocytes. Acta Biol Hung 61:411-422.

Pauluhn J (2004) Acute inhalation studies with irritant aerosols: Technical issues and relevance for risk characterization. Arch Toxicol 78:243-251.

Pistl J, Kovalkovicová N, Holovská V, Legáth J and Mikula I (2003) Determination of the immunotoxic potential of pesticides on functional activity of sheep leukocytes in vitro. Toxicology 188:73-81.
Rhind SM (2002) Endocrine disrupting compounds and farm animals: Their properties, actions and routes of exposure. Domest Anim Endocrin 23:179-187.

Siviková K and Dianovsky J (1999) Genotoxic activity of the commercial herbicide containing bifenox in bovine peripheral lymphocytes. Mutat Res 439:129-135.

Siviková K and Dianovsky J (2006) Cytogenetic effect of technical glyphosate on cultivated bovine peripheral lymphocytes. Int J Hyg Environ Health 209:15-20.

Stajnbaher D and Zupancic-Kralj L (2008) Optimisation of programmable temperature vaporiser-based large volume injection for determination of pesticide residues in fruits and vegetables using gas chromatography - mass spectrometry. J Chromatogr 1190:316-326.

Takahashi K (2009) Release rate of biocides from antifouling paints. In: Arai T, Harino H, Ohji M and Langston WJ (eds) Ecotoxicology of Antifouling Biocides. Springer, Tokyo/ Berlin/ Heidelberg/ New York, pp 3-22.

Tichá J, Hajslová J, Jech M, Honzícek J, Lacina O, Kohoutková J, Kocourek V, Lansky M, Kloutvorová J and Falta V (2008) Changes of pesticide residues in apples cold storage. Food Control 19:247-256.

Tielemans E, Louwerse E and de Cock J (1999) Exposure to fungicides in fruit growing: Re-entry time as a predictor for dermal exposure. Am Ind Hyg Assoc J 60:789-793.

Tucker JD and Preston RJ (1996) Chromosome aberration, micronuclei, aneuploidy, sister chromatid exchanges, and cancer risk assessment. Mutat Res 365:147-159.

Yoon JY, Oh SH, Yoo SM, Lee SJ, Lee HS, Choi SJ, Moon CK and Lee BH (2001) N-nitrosocarbofuran, but not carbofuran, induces apoptosis and cell cycle arrest in CHL cells. Toxicology 169:153-161.

\section{Internet Resources}

EPA, Pesticide Fact Sheet, http://www.epa.gov/opprd001/factsheets/tolylfluanid.pdf (February 25, 2010).

Pesticide Residues in Food -2002- Joint FAO/WHO Meeting on Pesticide Residues. Tolylfluanid, http://www.inchem.org/documents/jmpr/jmpmono/ 2002pr13.htm (February 7, 2010).

Associate Editor: Catarina S. Takahashi

License information: This is an open-access article distributed under the terms of the Creative Commons Attribution License, which permits unrestricted use, distribution, and reproduction in any medium, provided the original work is properly cited. 